Economic Hardships and Social Safety Net in Transition: Evidence from the Republic of Macedonia

\title{
移行化過程の国民の痛みと社会的セーフティネット 一マケドニア共和国を事例として一
}

\begin{abstract}
東海大学 千 年 篤
1989年の東欧革命以後、東欧の旧社会主義国の 新政府は民主主義化と市場経済化を柱とする体制 移行を推し進めてきた。市場化は経済効率を上昇 させ、経済成長を導き、国民の生活水準を向上さ せるものと期待された。しかし、非効率な経済シ ステムからの脱却は当初予想された以上に困難な ものであった。いずれの国も移行初期には実質所 得の减少、失業率の増加など国民生活水準の悪化 を強いられた。そして、国民間の所得格差の桩大 などに見られるように、市場経済化は国民間に勝 者と敗者という差別化を少なからずもたらした1。 はたして、旧東欧諸国における国民生活水準の悪 化や経済的格差の拡大は、実際どの程度のもので あったのだろうか。また、国民は直面している経 済的困難にどのように対処しているのであろうか。 本稿では、旧ユーゴ・マケドニア共和国を事例と して、以上の問題に関しての考察を試みる。

本稿の構成は以下のとおりである。まずマケド ニア移行経済の概況を述べた後、2節では地域間 格差と世帯間格差に主眼をおき、国民間の経済的 格差の拡大について分析する。3節では、国民経 済レベルと世帯レベルの両側面から、経済的困難 に対する国民の対応策を考察する。続く4節では、 国民の対応策を社会的セーフティネットの枠組み の中で整理・分析する。そこでは、ダグラス・ C・ノースの制度分析枠組みを援用し、セーフテ イネットを広義な意味で捉えて、フォーマルなセ

した市場移行過程は平坦なものではなかった。社 会主義時代の負の遺産である非効率的経済構造や 旧ユーゴ諸国間の戦争など新国家を取り巻く箃し い外的環境によって、GDPは独立以前の4分の3ま で落ち込んだ2。

表1は独立以後の主要マク口経済指標の推移を 示している3”。この中で特に注目すべきは、 $30 \%$ を超える失業率、政府支出の対GDP比の减少、貨 幣量の対GDP比の低さである。高い失業率は、独 立以前に形成された硬直的な労働市場構造と独立 以後の製造業の大幅な落ち込みと民有化によって 断行された大量の人員整理に由来する。政府支出 の减少は1994年にIMFの支援で開始された経済安 定化政策の下での緊縮財政政策の継続的実施を反 映している。貨幣量の少なさも経済安定化政策下 の緊縮金融政策に依抛するが、それは同時に貨幣 経済の未成熟さと外貨（特に、マルク）依存とい う国民経済体質を反映している。

表2は、独立直前の1990年及びそれ以後の実質 賃金水準と国民経済の中での従業員報酬総額（労 働所得）の動向を示している ${ }^{4)}$ 。独立以後、国民 生活水準が悪化したことは、この表からも明らか である。世界銀行は、独立直前の1991年には4\% に過ぎなかった貧困層の人口が、1996年には約 20\%に達したと推定している5)。ちなみに、1999 年の平均月純賃金は、9,664デナール（約160米ド

ル）に過ぎなかった。
\end{abstract} ーフティネットとインフォーマルなセーフティネ ットとに分類する。最終節はむすびに当てられる。

\section{1. マケドニア経済の概況}

1991年9月の国民投票を経て旧ユーゴ連邦から の独立を宣言したマケドニアは、他の東欧諸国同 様、民主化と市場化を柱とする体制転換を進めて きた。しかし、独立後これまでマケドニアが経験

\section{2. 経済的格差の拡大}

(1) 地域間格差

独立以後の地域間の経済的格差は、旧34ムニシ パリティ（オプシティナ）における1990年から 1995年（1991年の統計は非公表のため欠如）まで の一人当たり社会生産物（GSP）統計を用いて分 析された6)。各年の全国平均を 100 とした分析結果 
(単位: \%)

\begin{tabular}{|c|c|c|c|c|c|c|c|c|c|}
\hline & \multicolumn{3}{|c|}{ 混乱期 } & \multicolumn{3}{|c|}{ 安定化期 } & \multicolumn{3}{|c|}{ 回復・拡大期 } \\
\hline & 1991 & 1992 & 1993 & 1994 & 1995 & 1996 & 1997 & 1998 & 1999 \\
\hline 実質GDP成長率 & -12.1 & -21.1 & -9.1 & -1.8 & -1.2 & 0.8 & 1.5 & 2.9 & 2.7 \\
\hline 消費者物価指数変化率 & N/A & 1664.0 & 349.8 & 121.8 & 15.9 & 3.0 & 4.4 & 0.8 & -1.1 \\
\hline 失業率 & 19.2 & 27.8 & 28.3 & 31.4 & 37.7 & 31.9 & 36.0 & 34.5 & 32.4 \\
\hline 政府支出対GDP比 & N/A & 48.2 & 55.3 & 50.5 & 43.1 & 37.0 & 35.3 & 35.3 & 41.9 \\
\hline 財政収支対GDP比 & N/A & -9.6 & -13.4 & -2.9 & -1.2 & -0.5 & -0.4 & -1.8 & -1.5 \\
\hline 経常収支対GDP比 & N/A & N/A & 0.6 & -4.7 & -5.0 & -6.5 & -7.4 & -8.1 & -4.1 \\
\hline$M_{1}$ 対GDP比 & N/A & N/A & 9.5 & 7.2 & 7.4 & 6.9 & 7.6 & 7.9 & 10.1 \\
\hline $\mathrm{M}_{2}$ 対GDP比 & N/A & N/A & 22.9 & 12.2 & 11.0 & 10.5 & 12.3 & 13.5 & 16.8 \\
\hline
\end{tabular}

出所 : National Bank of the Republic of Macedonia, Bulletin, various issues.

EBRD, Transition Report, various issues.

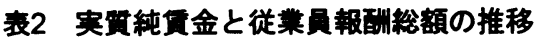

\begin{tabular}{|c|c|c|c|c|c|c|c|c|c|}
\hline & 1990 & 1991 & 1992 & 1993 & 1994 & 1995 & 1996 & 1997 & 1998 \\
\hline \multicolumn{10}{|c|}{ （1）実質純賃金の推移 $(1990=100)$} \\
\hline 全体 & 100 & 87.5 & 58.4 & 75.3 & 67.6 & 64.7 & 65.0 & 65.1 & 67.5 \\
\hline 経済部門 & 100 & 84.2 & 57.6 & 72.2 & 66.5 & 64.6 & 65.2 & 65.9 & 68.9 \\
\hline 非経済部門 & 100 & 94.9 & 57.7 & 79.3 & 64.5 & 58.0 & 57.1 & 55.8 & 56.8 \\
\hline \multicolumn{10}{|l|}{ （2）従業員報酬総額 } \\
\hline 対GDP比(\%) & 71.1 & 74.5 & 64.9 & 66.9 & 65.3 & 61.6 & 61.9 & 52.3 & N/A \\
\hline 内賃金・給与(\%) & 70.1 & 74.2 & 75.1 & 75.7 & 78.5 & 77.4 & 77.6 & N/A & N/A \\
\hline 推移 $(1990=100)$ & 100 & 90.3 & 62.6 & 70.1 & 74.2 & 70.1 & 71.6 & 61.8 & N/A \\
\hline
\end{tabular}

出所 : Statistical Office of the Republic of Macedonia, Statistical Yearbook of the Republic of Macedonia, various issues.

表3 ムニシパリティ別一人当たり社会生産物（GSP）の推移（全国平均=100）

\begin{tabular}{|c|c|c|c|c|c|}
\hline & 1990 & 1992 & 1993 & 1994 & 1995 \\
\hline 平均值 & 99.5 & 103.6 & 98.6 & 92.3 & 89.0 \\
最大值 & 249.2 & 238.3 & 324.8 & 362.0 & 371.5 \\
最小值 & 36.3 & 33.3 & 31.3 & 30.4 & 37.1 \\
標準偏差 & 45.2 & 46.5 & 54.6 & 61.0 & 62.0 \\
変動係数 & 0.45 & 0.45 & 0.55 & 0.66 & 0.70 \\
\hline 累積度数 & & & 5 & 5 & 7 \\
$<50$ & 4 & 5 & 13 & 19 & 19 \\
$<80$ & 14 & 11 & 21 & 25 & 26 \\
$<100$ & 18 & 17 & 32 & 31 & 31 \\
$<150$ & 32 & 30 & 34 & 34 & 34 \\
\hline 150 & 34 & 34 & & & \\
\hline
\end{tabular}

注）1991年のデータは公表されていない。

出所 : Statistical Office of the Republic of Macedonia, Statistical Yearbook of the Republic of Macedonia, various issues.

表4 年龄居別失菜苜（1997年4月1日現在）

\begin{tabular}{|c|c|c|c|c|c|c|c|}
\hline 年齢層 & $\begin{array}{l}\text { 就業可能 } \\
\text { 人口（人) }\end{array}$ & $\begin{array}{c}\text { 失業人口 } \\
\text { (人) }\end{array}$ & $\begin{array}{c}\text { 失業率 } \\
(\%)\end{array}$ & 年齢層 & $\begin{array}{l}\text { 就業可能 } \\
\text { 人口（人) }\end{array}$ & $\begin{array}{c}\text { 失業人口 } \\
\text { (人) }\end{array}$ & $\begin{array}{c}\text { 失業率 } \\
(\%)\end{array}$ \\
\hline $15 \sim 19$ & 37,014 & 29,759 & 80.4 & $45 \sim 49$ & 96,339 & 17,307 & 18.0 \\
\hline $20 \sim 24$ & 99,472 & 71,526 & 71.9 & $50 \sim 54$ & 58,427 & 8,051 & 13.8 \\
\hline $25 \sim 29$ & 110,665 & 59,530 & 53.8 & $55 \sim 59$ & 33,786 & 4,043 & 12.0 \\
\hline $30 \sim 34$ & 110,137 & 41,321 & 37.5 & $60 \sim$ & 21,538 & 1,578 & 7.3 \\
\hline $35 \sim 39$ & 117,771 & 31,669 & 26.9 & 不明 & 2,217 & 626 & 28.2 \\
\hline $40 \sim 44$ & 113,148 & 22,803 & 20.2 & 計 & 800,514 & 288,213 & 36.0 \\
\hline
\end{tabular}

出所 : Statistical Office of the Republic of Macedonia (1998), Statistical Yearbook of the Republic of Macedonia 1998. 
は表3にまとめられる。独立後、地域経済格差が 拡大したことは一目瞭然である。全国平均未満の ムニシパリティ数は1990年には18であったが、 1995年には26に增加した。また、相対的な散らば り度を示す変動係数で見ると、独立直前の1990年 では0.45であったのが、1995年には0.70と1.6倍に なった。

1995年の値と 1990年の値を比較すると、1995年 の值の方が高かったムニシパリティの数は僅かに 8に過ぎなかった。残り26ムニシパリティでは、 1995年の值が1990年の值よりも低かった。1995年 の全国平均一人当たり実質GSPは1990年水準の約 4分の3に過ぎなかったから、これら26ムニシパリ ティでは独立以後、一人当たりの経済水準が大幅 に低下したことが看取される。

1990-1995年間に相対的経済水準が向上した8 ムニシパリティは、首都を含むSkopje（5ムニシパ リティから構成）、Bitola、Tetovo、Gostivarなど いずれも国内有数の都市を持つ地域であった。特 に、Skopje中心部（Centar）の相対的水準の上昇 が際立っていた。国内第二の都市であるBitolaで も独立以後、相対的水準が上昇したが、Centar の経済格差は㧪大した。同様な現象がCentarの周 辺地域であるSkopjeの4ムニシパリティでも観察さ れた。TetovoとGostivarはアルバニア系住民が集中 する同国西部地方の中心都市を含むムニシパリテ ィで、独立以前から人口密度が高いため一人当た りの経済水準は低いが、比較的大きな地域経済を 有していた。

以上から、独立以後の地域間経済格差の動向は 次のように要約される。国内経済の悪化と共に地 域間の経済格差が拡大し、首都Skopje中心部への 一極集中化が進展した。その中で、地方都市を持 つ地域とSkopje中心部周辺地域においては独立以 後の生産下落幅が比較的小さかった。

独立以後の地域間格差拡大の要因を、1990年当 時の初期条件と1990-1995年の構造的変化の2側面 から定量的に分析した結果、1990年-1995年間に おける対全国平均一人当たりGSP水準の変化は、独 立直前の地域経済における商業シェアと有意な正
の相関関係があったことが確認されたク。つまり、 独立以前から商業が地域経済で重要な役割を担っ ていた地域ほど、移行化過程におけるショックに 対して柔軟に対処していたことが明らかになった。

\section{（2）世代間格差}

世代間の経済的格差は年齢層別失業率から分析 された。表4に見られるとおり、若年層の失業率 が非常に高いことがわかる。1997年の労働調査に よると、15～19歳層、20～24歳層、25～29歳層の 失業率は各々 $80 \% 、 72 \% 、 54 \%$ あった。独立後 の新卒者ら若年層が雇用面で最も被害を受けた世 代であることは、失業者数の7割以上が過去就労 経験のない者である事実からも看取できる（表 $5(1)$ 参照)。

マケドニアの労働市場は、独立以前から硬直的 構造を持っており、既職者は解雇されにくく、新 卒者など新規参入者が就職するのは難しかった。 この背景には、労働者自主管理制度の下、労働者 の権利が優先されたという制度的理由と、旧ユー ゴ連邦の近代化政策は各共和国の比較優位などに 注意を払わない画一的なもので、その結果として マケドニアにおいては十分な雇用機会が創出され なかったという経済政策の失敗が存在している8。 独立以後、製造業生産の大幅な落ち込みと民有化 が、さらなる労働需要の縮小に拍車をかけた。雇 用数の激减は真っ先に若年層を直撃した。企業に とっては、新規採用を控えるのが人員削减の遂行 にとって最も簡単で、従業員の抵抗の少ない方策 であったからである"。新卒者の学歷効果や就職 意欲の減退は求職期間が長くなるほど顕著となり、 それがさらなる失業期間の延長を招くといった悪 循環を生み出している（表5（2）参照）。

若年層同様、高年齢層も移行化過程で痛みを受 けた世代であった。平均年金給付額は1992年に平 均純貨金の83\%であったが、受給者数の増加と財 政悪化によって、1998年には74\%水準に減額され た。しかし、高齢者を含む中高年世代は社会主義 時代に居住していた社会有住宅や就労していた社 会有企業の株式などを優遇的に取得できる恩恵を 
受けていた ${ }^{10}$ 。また、独立以後、中高齢層の退職 者数が増加したことも見逃せない事実であるが、 比較的好条件下での早期退職者も多かった。以上 のことを考虑すれば、公有資産の分配対象外であ り、就職難に直面し且つ特定の社会保険受給権が ない若年層が移行化過程で経済的に最も被害を蒙 った世代であるといってよいだろう。

\section{3. 経斉的困難の中での国民の対応策}

\section{（1）国民経済から見た所得水準と消費水準}

図1は、国民会計統計から見た、1990-1996年 期間における国民の実質所得水準と塞質消費水準 の動向を表わしている。表6は、同期間中の実質 個人消費総額、実質従業員報酬総額（労働所得）、 実質賃金・給与総額の各々の平均、標準偏差、変 動係数をまとめたものである。図1から、個人消 費総額が、賃金・給与総額はもとより労働所得 （雇用主負担の社会保険料と所得税を含む）をも 上回っていたことがわかる。鷩くべきことに、平 均すると賃金・給与の 1.5 倍にあたる個人消費が実 現されていた。貨幣経済浸透度の低さ、ヤミ経済 の存在、社会保障制度の充実、経常所得として計 算されない収入源（資産売却や貯蓄の引き出しな ど）の存在などがその理由として考えられる。

図1と表6から明らかなように、個人消費は労働 所得や賃金・給与総額に比べて変動幅が小さい。 これは消費の平準化を志向する国民の消費行動を 反映しており、経済学における消費理論からも支 持される現象である。経常所得下落の中で、独立 以前の消費水準をなるべく維持しょうとしている こと、貨金・給与所得の下落分をそれ以外の収入 で補填していること、といった経済的困難の中で のマケドニア国民の行動様式が看取される。

\section{（2）家計から見十所得水準と消費水準}

1993-98年の家計調査結果を用いて計算された、 世帯構成員一人当たり実質経常収入と実質経常支 出（貯蓄込み）〈の概要は、表7にまとめられる。

表7から、いくつかの興味梁い結果が導かれる。 まず、総収入額と総支出額の変動幅には差が見ら
れなかったことがわかる。定職からの収入は、平 均すると総収入額の半分にも满たず、その変動幅 も大きい。定職からの収入减は、退職保険、臨時 的仕事などからの副収入と、保有財産の売却や貯 蓄（箪劄預金が主体）の引き出しなどの個人資産 の切り崩しによって、補填されていた。これは、 経常所得を上回る消費を実現したことを示す国民 会計統計とも整合する。また、退職保険以外の保 険の総収入に占める割合が増加していることも、 移行化過程の世帯収入の中で注目すべき点である。

一方、家計支出については、食費が総支出の4 割以上占めていることがまず注目をひく。食費は、 総支出や総消費と同様、1993年-1995年間には大 きく低下したが、1995年以降はほほ横這い状態で 推移している。家計支出に占める住宅費の低さは、 高い持ち家率とともに複数世帯の同居がマケドニ アでは一般的な居住形態であるという状況を反映 している。しかし、他の支出項目の実質支出額が 堿少している中で、住宅費は低率ながらも上昇し

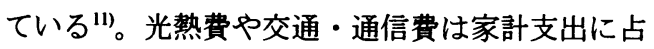
める比率が7-8\%と比較的高く、その変動幅が小 さかった。これは電気や車両の利用がマケドニア での一般生活には不可欠であるという事情を反映 している。衣服・靴支出の変動が大きいのは、経 済的困難の中、国民がそれらの支出を押さえる傾 向にあったことを示している。

また、非常に興味深いことは、貯蓄はその変動 幅が大きいとはいえ、平均すると総支出の $11.8 \%$ をも占めていたことである。これは一見すると、 収入の方では賃金所得の低下を保有資産や貯蓄の 切り崩しで補っていた事実と矛盾するように見え る。この主な理由は、ここで分析に用いられた数 值がすべて家計調查の全サンプル世帯を対象にし た一人当たりの平均であるために起こった集計上 の問題であると考えられる。しかし同時に、マケ ドニア国民の貯蓄性向を反映しているとも考えら れる。経済的困難の渦中でも、貯蓄をするという 行動様式は、過去の歴史において旧ユーゴ連邦時 代を除くと常に周辺強国の領土的野心の対象に晒 されていたため、生活環境の劇的変化に対応でき 
表5 求職者数類型別内訳（1997年12月31日現在）

(単位 : 人、（）内\%)

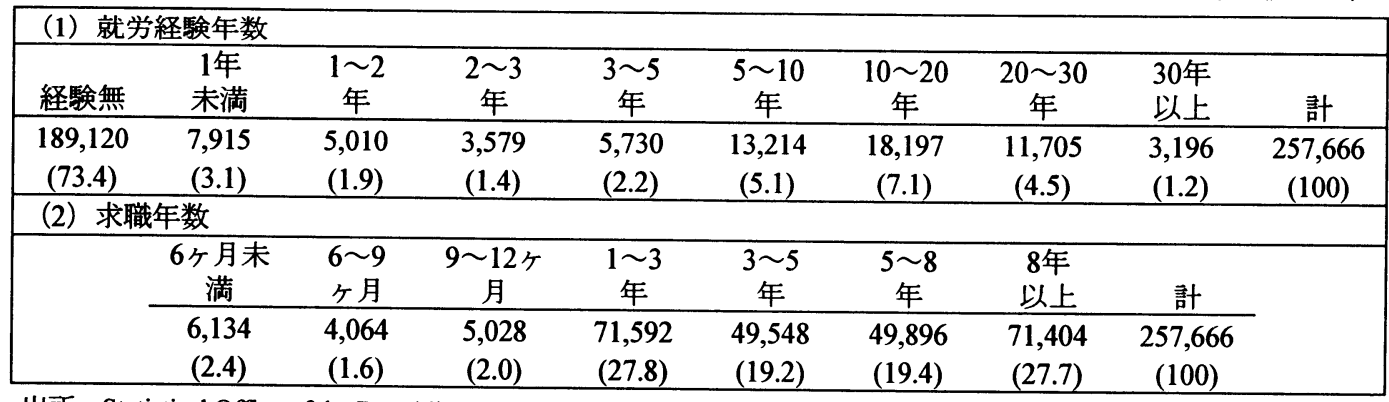

出所 : Statistical Office of the Republic of Macedonia (1998), Statistical Yearbook of the Republic of Macedonia 1998.

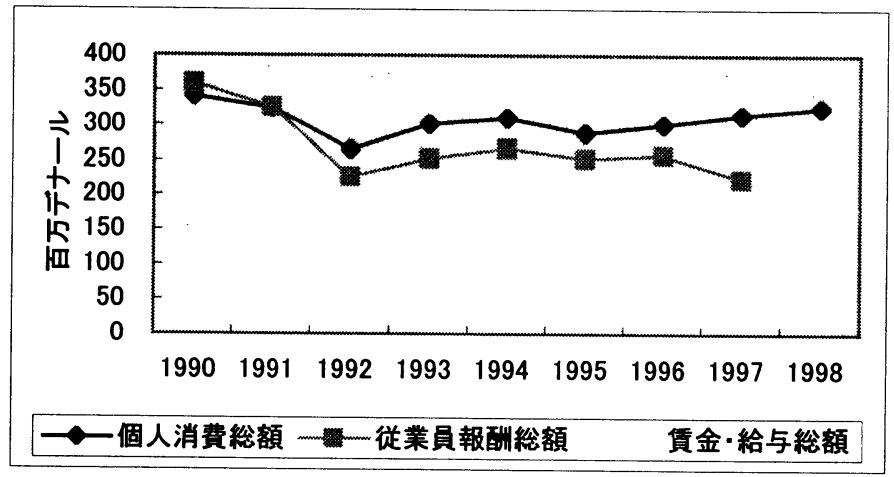

図1 個人消費 - 従業員報酬総額・軼金給与総額の推移（1990年価格）

出所 : Statistical Office of the Republic of Macedonia, Statistical Yearbook of the Republic of Macedonia, various issues.

表6 実質個人消費総額・従業員報酬総額・貢金総額の実繈（1990-1996年）

（単位 : 百万デナール、1990年価格）

\begin{tabular}{|c|ccc|}
\hline & 平均 & 標淮偏差 & 変動係数 \\
\hline 個人消費総額 & 304.0 & 22.7 & 0.07 \\
従業員報酬纉 & 276.9 & 43.9 & 0.16 \\
顀金・給与総額 & 208.2 & 26.9 & 0.13 \\
\hline
\end{tabular}

出所 : Statistical Office of the Republic of Macedonia, Statistical Yearbook of the Republic of Macedonia, various issues.

表7家計収入・支出の内訳 (1993-1998年)

（単位：1993年価格デナール、（）内\%)

\begin{tabular}{|c|c|c|c|c|c|c|c|c|c|}
\hline \multicolumn{10}{|c|}{ （1）一人当たり平均実質収入 } \\
\hline & 計 & $\begin{array}{l}\text { 貨幣 } \\
\text { 収入 }\end{array}$ & $\begin{array}{l}\text { 定期的 } \\
\text { 仕事 }\end{array}$ & $\begin{array}{l}\text { 臨時的 } \\
\text { 仕事 }\end{array}$ & $\begin{array}{l}\text { 財産 } \\
\text { 売却 }\end{array}$ & $\begin{array}{l}\text { 退職 } \\
\text { 保険 }\end{array}$ & $\begin{array}{l}\text { その他 } \\
\text { 保険 }\end{array}$ & $\begin{array}{c}\text { 貯蓄の } \\
\text { 引出 }\end{array}$ & その他 \\
\hline 平均 & 20,375 & 18,738 & 9,747 & 972 & 1,781 & 3,015 & 522 & 1,234 & 1,466 \\
\hline & (100) & (92.0) & $(47.8)$ & (4.8) & (8.7) & (14.8) & (2.6) & (6.1) & (7.2) \\
\hline 標準偏差 & 1,588 & 1,467 & 1,692 & 118 & 322 & 489 & 190 & 637 & 387 \\
\hline 変動係数 & 0.08 & 0.08 & 0.17 & 0.12 & 0.18 & 0.16 & 0.36 & 0.52 & 0.26 \\
\hline \multicolumn{10}{|c|}{ (2) 一人当たり平均実質支出 } \\
\hline & 計 & $\begin{array}{l}\text { 個人 } \\
\text { 消費 }\end{array}$ & 食費 & $\begin{array}{c}\text { 衣服・ } \\
\text { 靴費 }\end{array}$ & 住居費 & 光熱費 & $\begin{array}{l}\text { 交通・ } \\
\text { 通信費 }\end{array}$ & $\begin{array}{l}\text { 医療・ } \\
\text { 衛生費 }\end{array}$ & 貯蓄 \\
\hline 平均 & $\begin{array}{r}20,297 \\
(100)\end{array}$ & $\begin{array}{r}17,153 \\
(84.5)\end{array}$ & $\begin{array}{c}8,630 \\
(42.5)\end{array}$ & $\begin{array}{r}1,333 \\
(6.6)\end{array}$ & $\begin{array}{r}377 \\
(1.9)\end{array}$ & $\begin{array}{r}1,584 \\
(7.8)\end{array}$ & $\begin{array}{r}1,465 \\
(7.2)\end{array}$ & $\begin{array}{r}1,002 \\
(4.9)\end{array}$ & $\begin{array}{r}2,389 \\
(11.8)\end{array}$ \\
\hline 標準偏差 & 1,600 & 1,133 & 657 & 221 & 35 & 58 & 123 & 73 & 550 \\
\hline 変動倸数 & 0.08 & 0.07 & 0.08 & 0.17 & 0.09 & 0.04 & 0.08 & 0.07 & 0.23 \\
\hline
\end{tabular}

出所 : Statistical Office of the Republic of Macedonia, Statistical Yearbook of the Republic of Macedonia, various issues. 
るように日頃から蓄財をしておく傾向にあったマ ケドニア民族の伝統によるものかもしれない(12)。

\section{4. 社会的セーフティネット}

本節では、前節で見た経済的困難の中でもマケ ドニア国民の対応策について、社会的セーフティ ネットの枠組みを用いて整理・考察を試みる。ダ グラス・C・ノースの制度分析枠組みを援用して、 フォーマルなセーフティネットとインフォーマル なセーフティネットとに分類する。フォーマルな セーフティネットとは、社会保険制度などフォー マルな制度によるリスク分散機能であり、それは 一般に言われている社会的セーフティネットのこ とを指す。一方、インフォーマルなセーフティネ ットは伝統、慣習、行動規範などインフォーマル な制度の枠の中で形成されているリスク分散機能 である、と本稿では定義する。

\section{(1) フォーマルなセーフティネット}

現行のフォーマルなセーフティネットは、失業 保険、老齢年金、医療保険などに代表される社会 保障制度である。この社会保障制度は、独立以後 の経済的困難の中で国民生活水準悪化の緩和に貢 献した。独立以後、减少した世帯収入における退 職保険やその他の社会保険の重要性は前節で見た 通りである。また、医療保険制度の充実は、国民 生活の悪化の状況下でも世帯支出の中で医療関係 支出が安定して比較的低位で推移していたことか らも推察できよう。

社会保障制度の充実は社会主義時代の制度遺産 である。しかし、移行化過程では現行社会保険制 度運用の維持が困難になってきている。保険給付 額の増大と保険徵収額の减少は、経済悪化による 賃金水準の低下と失業者の増大による必然的な結 果であり、現在、社会保険基金は破産寸前の危機 に陥っている。1997年における対GDP社会保障支 出比率は、医療保険 $6.2 \%$ 、年金 $10.2 \%$ 、児童手 当・生活保護などの社会福祉プログラム $3.7 \%$ であ り、その合計支出は政府支出の $51.1 \%$ 占めてい る $^{13)}$ 。また、経済悪化に伴う、新規受給資格者の
增大の中で、本来受給資格がない者が受給してい たり、逆に受給資格を満たす者が受給していなか ったりで、その運営効率性の問題も生じている ${ }^{14}$ 。 現在、現行の社会保障制度は各種社会保険基金 破産の回避から、その抜本的改革の必要に迫られ ている。特に、失業保険と年金の制度改革は、政 府財政負担の軽減の他にも、市場経済の発達には 不可欠なものと認識されている。労働者に手厚い 現行の失業保険と年金制度が労働市場の硬直的構 造の一因であり、西側の先進諸国に比較して企 業・債権者の権利が弱いために、内外投資家のマ ケドニアにおける投資拡大の一阻害要因になって いる(1)。

このような状況の中で、従来のセーフティネッ トを補完する新たなセーフティネットの構築が模 索されている。そのひとつとして注目されるのが 農村・農業の社会的・経済的機能の活用である。 1994年に開始された地域開発計画は、国境周辺地 域、中山間地、経済的不利地域など経済的未発展 地域における、農村生活・農業生産インフラの整 備に重点をおいて、広範囲に小規模な開発事業を 展開している。農村部の生活環境の向上と潜在的 経済資源の活用によって、都市部で失職した者の 帰村及び定住化を促進することが目標とされてい る。未発展地域における㕍用創出と生活環境の向 上は、移行化過程で扡大している地域間経済格差 の是正と、首都Skopje一の経済一極集中化に誘引 される首都への人口集中化の防止にも貢献する ${ }^{16}$ 。 地域開発計画は多面的な目的を持っているが、都 市部で失職した者にセカンド・チャンスを与える という一側面に注目すれば、マケドニア社会にお けるセーフティネット機能を払充する政策と捉え ることができる。より広義に見るならば、年金や 生活扶助など世代間・世帯間の所得移転機能に偏 重している従来のセーフティネットから、地域間 格差緩和機能も含んだ多面的なセーフティネット への再編が企図されているとも言える。加えて、 地域開発計画は地域住民の自助努力による中・長 期にわたる自発的発展を後押しする誘導政策であ るから、その実施によって従来の対症療法的なセ 
ーフティネットに自律的、持続的性格が導入され ることになり、この点でもセーフティネットの多 面化に寄与することになろう。

\section{(2) インフォーマルなセーフティネット}

独立以後の経済的困難の中、マケドニア国民は その痛みを個人としてではなく家族で受け止めて いる傾向にある。すなわち、家族制度が一種のセ ーフティネットとして機能している。これは、マ ケドニアでは失業者の4分の3が貧困層には属して いないという事実に反映されているゆ。失業と貧 困の不一致は、失業給付など社会保障制度の存在 がその一因でもあるが、それ以上に失業という個 人の痛みを家族単位で吸収しているという国民の 行動様式に依るところが大きい。

独立後に拡大している世代間格差は、家族内で の所得移転や資産共有によって緩和されている。 マケドニアでは複数世代の同居が普通で、若年齢 層の多くが親と同居することによって生活費を切 りつめている。かりに定職に就いていても月給で は貨貸住宅の家貨を支払えないため、結婚後も親 の保有するアパートに居住したり、改築や建て増 しをした親の住居の中に新世帯を構えたりするの が一般的である。家計支出の中で住宅費が低率な のは前節で述べたとおりである。また、世帯収入 源の多様化も血縁組織内の協力があるからこそ、 可能となっている。雇用情報の交換（縁故採用も 含む）や受給社会保険（特に老龃年金）の私的移 転は、血縁的結びつきがベースになるからである。 血縁的結びつきをべースにした相互扶助は、同 居家族内のみならず地域間の所得移転にも及ぶ。 とりわけ重要な所得移転は、西欧諸国や北米、才 一ストラリアなど海外で働く身内からの送金であ る。家計調査の中では特定収入源として計上され てないが、海外からの送金が世帯収入の中で少な からぬ役割を担っているのは間違いない(18)。また、 農村に住む親類縁者からの食料調達、都市で働く 者から農村にいる家族への現金授与、親族間の生 活物資（衣服など）の授受などはマケドニア社会 ではごく一般的に行われている。このような地域
間の私的移転が、独立後影著になった地域間格差 の悪化の緩和に貢献している。

家族制度はマケドニアの伝統である。マケドニ ア人は中世から近代に至るまで常に近隣強国の被 支配層であり、度重なる境界及び支配者の変化を 経ながらも、独自の宗教、文化、習慣を維持して きたが、この地域社会の安定は血縁的関係を基礎 とする農村共同体（ザドルガ）に支えられていた という歷史的背景に注意を払う必要ある ${ }^{19}$ 。過去 の歴史と同様に、強い血縁的結びつきというイン フォーマルなセーフティネットがあったからこそ、 マケドニアでは独立後の厳しい経済的困難の中で も国内不满分子が爆発して政治的・社会的混乱を 招くような事態まで発展しなかったのかもしれな い。

\section{5. むすび}

本稿では、旧東欧諸国に観察される生活水準の 悪化や経済的格差の拡大という体制移行過程での 負の側面に着目して、旧ユーゴ・マケドニア共和 国を対象に定量的分析に基づいてその考察を試み た。その結果、首都Skopjeへの一極集中化、若年 層がもっとも被害を受けたという、体制転換後の 経済的格差の特性が浮彫りにされた。さらに、失 業や実質賃金の减少による実質所得の下落という 経済的困難に直面しながらも、国民は複数収入源 から収入を得るとともに、食料、住宅、衣服への 支出を倹約して、生活水準の悪化を緩和していた ことが明らかになった。そこでは、社会保障制度 というフォーマルなセーフティネットに加えて、 家族制度というインフォーマルなセーフティネッ トが重要な役割を果たしていた。

強い絆を持つ家族制度はマケドニアのみならず バルカン社会で広く共有される伝統である。その 意味で、本稿で用いたセーフティネットに着目し た分析枠組みは、他バルカン諸国における体制移 行過程の国民生活の現状を分析する際にも有用に なると思われる。 
* 大会当日、座長羽場久浘子先生（法政大学）、 討論者岩田昌征先生（千葉大学）、その他数 人の会員の方々から貴重なコメントを頂いた。 記して感謝申し上げたい。

$<$ 注 $>$

1)旧東欧諸国における移行化過程の社会厚生的 側面の悪化については、羽場（1998）や Hutton and Redmond (eds.)（2000）などを参照。

2) 統計データの出所先は、Statistical Office of the Republic of Macedonia, Statistical Yearbook of the Republic of Macedonia（『統計年報』）の各年 版。以下本稿で用いられている各種統計デー 夕の出所先は、ことわりがない限り『統計年 報』もしくはNational Bank of the Republic of Macedonia, Bulletinの各4半期版である。

3) 独立後の経済政策や経済成果の詳細について は、千年（2000）を参照。

4) 実質賃金は生活費指数（CPIに相当）でデフ レートして算定されている。以下、所得や消 費など貨幣表示変数の実質化についても同様。

5) World Bank (1999), p.ii.

6) 1996年以降、GSP統計は公表されていないこ と、また1997年に行政区分が変更されたこと （現在は123ムニシパリティ）の2つの理由に より、分析は限定的にならざるを得なかった。

7) 紙幅の制約上、詳細な分析手順とその結果は 別稿に譲る。

8)旧ユーゴ連邦の経済システムや経済政策につい ては、阿部（1993）、Gapinsiki（1993）、岩田 （1994）などを参照。

9) World Bank (1998), pp.61-62.

10) マケドニアでは既に社会有住宅の私有化はほ ぼ終了している。公共住宅管理局が管理する 住宅数は1992年には57千戸であったが、1998 年には7千戸となった（World Bank (1998), p.69）。住宅の所有権転換に関してひとつ注 意すべきことは、富裕層がより大きな恩恵を 受けていた事実である。旧ユーゴ時代に、社 会有住宅に優先的に居住することができた者
は党・政府の有力者や社会有企業の経営者で あり、独立後、彼らは以前から居住している 賃貸住宅を市場価格より大幅に下回る価格で 購入することができたからである。

11) 独立以後、住宅の供給不足によって貸貸住宅 の実質家賃が上昇していることがその主因で ある。1993-1998年期間の家賃・水道の平均 価格上昇率は 48.8\%で、生活費指数上昇率 (22.6\%) を大きく上回っていた。ちなみに、 同期間の他項目価格上昇率は、食料 $20.3 \%$ 、 衣服・靴 $19.9 \%$ 、光熱 $20.8 \%$ 、交通 - 通信 $25.3 \%$ あ゙あった。

12) 旧ユーゴ時代においても、スロヴェニアやク ロアチアに比較して所得水準がかなり低かっ たにもかかわらず、マケドニアの平均貯蓄率 はそれら北の先進国よりも高かった（Sts. Cyril and Methodius University (スコピエ大 学) 法学部Jane Miljovski教授からの聞き取り、 2000年2月）。

13) World Bank (1998), p.13.

14) World Bank (1999), pp. 61-62.

15) World Bank (1998), p.66.

16) 地方開発促進の背景には、中央政府から地方 政府への交付金が近年の督縮財政政策によっ て圧迫されているという事情もある。現在、 地方政府は固定資産税、相続税、不動産取引 税など限定的財源しか持っていない。また、 国境辺境地域での定住化維持 - 促進は新独立 国にとっては国防上重要である。

17) World Bank (1999), p. 29.

18）1999年の公式統計では海外からの送金は63百 万ドル過ぎないが、実際は闇ルートからの送 金がその数倍になると推定されている。マケ ドニアにおけるヤミ経済の規模はGDPの30\% に達するとも言われているが、闇ルートから の海外送金もその重要な一構成要素である。

19) ザドルガ及び旧ューゴ連邦各共和国のザドル ガ家族形態については越村（1991、1994）を 参照。また、マケドニアの民族的・社会的特 性や歷史については、Muhic（1996）や 
Pettifer（1999）などを参照。

\section{〈参考文献〉}

・阿部 望（1993）『ユーゴ経済の危機と崩 壊』日本評論社.

-千年 篤 (2000)「マケドニアの移行経済の成 果と構造 : 基底的要素に焦点をあてて」『行 動科学研究』Vol. 52, pp. 63-80.

- Dyker, D. A., and I. Vejvoda (eds.) (1996), Yugoslavia and After, Longman, London.

- European Bank for Reconstruction and Development, Transition Report, various issues, European Bank for Reconstruction and Development, London.

- Gapinsiki, J. H. (1993), The Economic Structure and Failure of Yugoslavia, Praeger, Westport.

・羽場久湦子（1998）『拡大するョーロッパ： 中欧の模索』岩波書店.

- Hutton, S., and G. Redmond (eds.) (2000), Poverty in Transition Economies, Routledge, London.

・岩田昌征（1994）『ユーゴスラヴィア：衝突 する歷史と抗争する文明』NTT出版.

- 越村 勲（1991）「社会」柴編（1991）, pp. 151-176.

- 越村 勲 編訳（1994）『バルカンの大家族 ザドルガ』彩流社.

- Muhic, F. (1996), "Macedonia-an Island on the Balkan Mainland," in Dyker, D. A., and I. Vejvoda (eds.) (1996), pp.232-247.

- National Bank of the Republic of Macedonia, Bulletin, various issues, National Bank of the Republic of Macedonia, Skopje.

- North, D.C. (1990), Institutions, Institutional Change and Economic Performance, Cambridge U. Press, New York.

- Pettifer, J. (ed.) (1999), The New Macedonian Question, Macmillan Press, London.

- 柴宣弘 編 (1991) 『もっと知りたいユー ゴスラヴィア』弘文堂.

- Statistical Office of the Republic of Macedonia, Statistical Yearbook of the Republic of Macedonia, various issues, Skopje.

- World Bank (1998), FYR Macedonia: Country Economic Memorandum-Enhancing Growth, World Bank.

- World Bank (1999), Former Yugoslav Republic of Macedonia: Focusing on the Poor, World Bank. 


\section{Economic Hardships and Social Safety Net in Transition: Evidence from the Republic of Macedonia.}

Atsushi Chitose

(Tokai University)

It is widely noted that former socialist countries in Eastern Europe have suffered from the deterioration in social well-being during the period of transition to a market economy. How seriously has the living standard of people actually been threatened? To what extent has income inequality widened? In addition, how have people coped with economic hardships during the transition? This paper attempts to address these questions using quantitative measures where possible, with the Republic of Macedonia as a case of study. The focus is placed on the countermeasures taken by the people against economic hardships within the framework of social safety net.

It is found that income inequality has widened across regions, accompanied by a concentration of economic activities in Skopje, the capital of the Republic. Also, economic inequality in the society has widened across generations; the young generation has been affected most seriously. In these contexts, people try to alleviate the deteriorating living standard by gaining income from multiple sources (including transfers from various social welfare programs, a withdrawal of savings and sales of properties) and by reducing daily expenditures such as for food, and clothes and shoes.

In Macedonia, a formal safety net such as social welfare programs has undoubtedly helped sustain the level of living standard to a certain extent during the transition. However, at the same time the family system that is regarded as an informal safety net has played an important role in alleviating the declining living standard as well as in the widening of economic inequality both across regions and across generations during the transition.

The family system with strong kinship ties is the distinct characteristic observed in Balkan societies. Thus, the analytical framework based on social safety net introduced in this paper is expected to provide a useful approach in analyzing social welfare problems in other Balkan countries during the period of transition to a market economy.

Key words: Macedonia

inequality in transition

countermeasures against economic hardships

social safety net 